Inventa: Jurnal Pendidikan Guru Sekolah Dasar

http://jurnal.unipasby.ac.id/index.php/jurnal_inventa

\title{
PENGEMBANGAN PERANGKAT PEMBELAJARAN BERBASIS MODEL PBL PADA SUBTEMA KOMPONEN EKOSISTEM UNTUK PESERTA DIDIK KELAS V SD DI KABUPATEN REMBANG
}

\author{
Febry Puspita Diningtyas ${ }^{1)}$, Fine Reffiane ${ }^{2)}$, dan Ryky Mandar Sary ${ }^{3)}$ \\ Prodi PGSD FIP Universitas PGRI Semarang \\ Corresponding author E-mail: febrypuspita10@gmail.com
}

\begin{tabular}{ll}
\hline & \multicolumn{1}{c}{ Abstrak } \\
\hline Kata Kunci: & Tujuan penelitian ini adalah mengembangkan perangkat pembelajaran berbasis \\
perangkat & model PBL pada subtema komponen ekosistem untuk peserta didik kelas V Sekolah \\
pembelajaran, & Dasar yang memenuhi kriteria kualitas: valid, praktis dan efektif. Jenis penelitian ini \\
Problem Based & adalah penelitian dan pengembangan dengan menggunakan model ADDIE yang \\
Learning, Sekolah & terdiri dari 5 tahap yaitu tahap analysis (analisis), design (perancangan), \\
Dasar & development (pengembangan), implementation (implementasi) dan evaluation \\
& (evaluasi). Teknik analisis data yang digunakan pada penelitian ini merupakan \\
& deskripsi kuantitatif dan kualitatif. Hasil penelitian menunjukkan bahwa masing- \\
& masing produk memenuhi kriteria valid, praktis, dan efektif. Produk memenuhi \\
& kriteria valid ditunjukkan dari persentase uji validasi ahli materi dan media, \\
& perangkat pembelajaran (silabus dan RPP) mencapai persentase 90,51\% dan modul \\
& bahan ajar mencapai persentase 91,05\%. Produk memperoleh kriteria kepraktisan \\
& ditunjukkan dari persentase tanggapan guruterhadap perangkat pembelajaran \\
& (silabus dan RPP) mencapai 89,52\% dan modul bahan ajar mencapai 88\% dan \\
& persentase tanggapan peserta didik sebesar 86,06\%. Produk memenuhi kriteria \\
& keefektifan berdasarkan hasil belajar peserta didik pada kompetensi sikap, \\
& pengetahuan, dan keterampilan. Persentase peserta didik yang mencapai KKM \\
& untuk kompetensi pengetahuan melebihi rata-rata 83,78 dengan klasifikasi "tinggi". \\
& Kesimpulannya, perangkat pembelajaran berbasis model PBL layak digunakan. \\
\hline
\end{tabular}

\section{Abstract:}

Keyword:

learning tools,

Problem Based

Learning, Elementary

School
The purpose of this study was to develop learning tools based on the PBL model on the sub-theme of ecosystem components for grade $\mathrm{V}$ elementary school students who meet the quality criteria: valid, practical and effective. This type of research is research and development using the ADDIE model which consists of 5 stages, namely the analysis, design, development, implementation and evaluation stages. The data analysis techniques used in this study are quantitative and qualitative descriptions. The results showed that each product met the criteria of validity, practicality, and effectiveness. The product meets the valid criteria indicated by the percentage of the material and media expert validation test, the learning tools (syllabus and lesson plans) reach a percentage of $90.51 \%$ and the teaching material module reaches a percentage of $91.05 \%$. The product obtained the criteria of practicality indicated by the percentage of teacher responses to learning tools (syllabus and lesson plans) reaching $89.52 \%$ and teaching material modules reaching $88 \%$ and the percentage of student responses of $86.06 \%$. The product meets the effectiveness criteria based on the learning outcomes of students on the competence of attitudes, knowledge and skills. The percentage of students who reached the KKM for knowledge competencies exceeded the average of 83.78 with the "high" classification. In conclusion, the PBL model based learning tools are feasible to use. 


\section{Pendahuluan}

Pendidikan merupakan suatu proses kegiatan belajar mengajar yang dilakukan oleh guru kepada peserta didik berupa ilmu pengetahuan, keterampilan maupun sikap (Wicaksono, 2018). Kegiatan belajar mengajar menjadi sarana dan prasarana yang sangat penting untuk kebutuhan manusia, yaitu untuk menyiapkan sumber daya manusia yang berkualitas demi tercapainya tujuan pendidikan bagi pembangunan bangsa dan negara (Yusuf, 2018). Hal ini sesuai dengan UU Republik Indonesia No. 20 tahun 2003 tentang Sistem Pendidikan Nasional, dalam Bab 1 Pasal 1 Ayat 1 disebutkan bahwa:

"Pendidikan adalah usaha sadar dan terencana untuk mewujudkan suasana dan proses pembelajaran agar peserta didik secara aktif mengembangkan potensi dirinya untuk memiliki kekuatan spiritual keagamaan, pengendalian diri, kepribadian, kecerdasan, akhlak mulia, serta keterampilan yang diperlukan dirinya, masyarakat, bangsa dan negara."

Menurut Minggele (2019), untuk mewujudkan tujuan pendidikan tersebut, maka dunia pendidikan dituntut untuk selalu berubah dan berkembang sesuai dengan perkembangan Ilmu Pengetahuan dan Teknologi (IPTEK) dan kebutuhan peserta didik. Dalam dunia pendidikan sangat berkaitan erat dengan peserta didik, oleh karena itu, guru harus bisa menciptakan kegiatan pembelajaran yang aktif dan menarik agar suasana pembelajaran menjadi lebih menyenangkan dan peserta didik terlibat aktif dalam proses pembelajaran sehingga dapat meningkatkan prestasi dan semangat belajar peserta didik (Minggele, 2019). Hal tersebut terwujud dengan adanya kegiatan belajar mengajar yang menggunakan kurikulum 2013 dan kegiatan pembelajarannya menggunakan pembelajaran tematik terpadu (Machali, 2014).

Machali (2014), menyatakan bahwa,

Pembelajaran tematik terpadu merupakan pendekatan pembelajaran yang mengintegrasikan berbagai kompetensi dari berbagai mata pelajaran ke dalam berbagai tema. Pengintegrasian tersebut dilakukan dalam dua hal, yaitu integrasi sikap, keterampilan dan pengetahuan dalam proses pembelajaran dan integrasi berbagai konsep dasar yang berkaitan. Tema merajut makna berbagai konsep dasar sehingga peserta didik tidak belajar konsep dasar secara parsial. Dengan demikian pembelajarannya memberikan makna yang utuh kepada peserta didik seperti tercermin pada berbagai tema yang tersedia.

Oleh karena itu, implementasi Kurikulum 2013 diyakini sebagai langkah strategis dalam menyiapkan dan menghadapi tantangan globalisasi dan tuntutan masyarakat Indonesia masa depan. Kompetensi masa depan yang diperlukan dalam menghadapi arus globalisasi antara lain berkaitan dengan 
kemampuan berkomunikasi, kemampuan berpikir jernih dan kritis, kemampuan mempertimbangkan segi moral suatu permasalahan, kemampuan menjadi warga Negara yang bertanggungjawab, kemampuan mencoba untuk mengerti dan toleran terhadap pandangan yang berbeda, dan kemampuan hidup dalam masyarakat yang mengglobal (Machali, 2014).

Hal ini sejalan dengan pendapat Trisdiono dalam (Herayanti, 2018) yang mengatakan bahwa, Partnership for 21st Century Skills mengidentifikasi kecakapan abad 21 meliputi: berpikir kritis, pemecahan masalah, komunikasi dan kolaborasi. ini peserta didik. Jadi, diperlukan kegiatan pembelajaran dengan menggunakan model PBL, karena dalam Problem Based Learning atau yang lebih dikenal dengan PBL, suasana pembelajaran berbasis masalah akan mendorong siswa untuk menemukan terlebih dahulu cara atau strategi sebelum menyelesaikan permasalahan yang diajukan. Ini berarti bahwa pembelajaran akan lebih bermakna dengan berbasis pada suatu permasalahan (Sary, 2015).

Dalam kurikulum 2013 terdapat suatu perangkat pembelajaran. Perangkat pembelajaran merupakan perlengkapan kegiatan pembelajaran dibuat dan disusun secara sistematis yang digunakan oleh guru dalam proses pembelajaran. Perangkat pembelajaran yang efektif dan efisien juga dapat mengoptimalkan interaksi antara peserta didik dengan peserta didik atau peserta didik dengan guru selama kegiatan pembelajaran berlangsung. Perangkat pembelajaran yang baik adalah perangkat pembelajaran yang dapat menunjang pembelajaran sehingga tujuan yang diharapkan dalam pembelajaran dapat tercapai (Minggele, 2019). Perangkat pembelajaran yang dibuat dalam penelitian ini meliputi silabus, RPP (Rencana Pelaksanaan Pembelajaran), modul bahan ajar, dan LKPD. Penyusunan perangkat merupakan tahap awal dalam pembelajaran. Oleh sebab itu, kualitas perangkat yang digunakan juga menentukan kualitas pembelajaran. Untuk menghasilkan perangkat berkualitas baik maka perangkat pembelajaran harus disusun dengan matang (Kusmayadi \& Riyadi, 2016; Tanjung, 2018).

Berdasarkan observasi awal yang dilakukan peneliti terhadap salah satu perangkat pembelajaran yang digunakan di SDN 2 Logede, terdapat beberapa kelemahan yang perlu diperbaiki. Kelemahan pertama, dalam RPP belum menuliskan model pembelajaran yang akan digunakan dalam proses belajar mengajar. Kelemahan kedua, dalam langkah-langkah kegiatan pembelajaran tidak disusun secara sistematis yang dimulai dari kegiatan pendahuluan, kegiatan inti, dan kegiatan penutup, namun langsung dijadikan satu, tidak ada keterangan yang membeda antara kegiatan pendahuluan, inti, dan penutup. Menurut peneliti, dalam langkah- 
langkah pembelajaran hanya berisi kegiatan inti, tidak terdapat kegiatan pendahuluam dan penutup. Kelemahan ketiga, belum adanya keterangan sumber belajar dalam RPP. Kelemahan keempat, tidak tersedianya lembar kerja peserta didik (LKPD) dalam proses pembelajaran, sementara ketersediaan LKPD ini sangat membantu siswa melakukan penyelidikan atau pemecahan masalah. LKPD dapat berupa panduan untuk pengambangan aspek kognitif maupun pengembangan semua aspek pembelajaran dalam bentuk panduan eksperimen. Dengan adanya LKPD, diharapkan pemahaman siswa akan materi yang diajarkan akan lebih maksimal. Berdasarkan kegiatan wawancara dengan guru kelas V di SDN 2 Logede, SDN Kedungtulup, dan SDN 1 Sendangmulyo, kegiatan pembelajaran hanya berpusat pada buku tematik dan LKS, belum ada sumber belajar lain yang digunakan oleh guru.

Kelemahan-kelemahan ini menunjukkan bahwa kualitas perangkat pembelajaran yang tersedia belum tergolong baik. Hal ini juga didukung oleh fakta bahwa perangkat yang dikembangkan oleh guru belum pernah diuji validitas, kepraktisan maupun keefektifannya. Sementara, ketiga hal ini merupakan kriteria yang harus dipenuhi dalam mengembangkan perangkat pembelajaran. Perangkat yang dikembangkan juga akan memenuhi kriteria valid, praktis dan efektif (Tanjung, 2018).
Selain itu, berdasarkan hasil wawancara dengan guru kelas V di SDN 2 Logede, SDN Kedungtulup, dan SDN 1 Sendangmulyo, masih terdapat banyak peserta didik yang belum aktif. Keaktifan tersebut adalah kegiatan peserta didik dalam mendengarkan penjelasan guru, kegiatan bertanya, kegiatan berkelompok, bekerjasama dengan teman dalam satu kelompok, menyiapkan alat pelajaran, memecahkan masalah dalam kelompok, menggali informasi, melakukan cara kerja pengamatan sesuai petunjuk, menyusun hasil pengamatan dalam bentuk laporan dan menyampaikan kesimpulan hasil pengamatan (Susanto, 2012). Peserta didik masih belum terlibat aktif dalam aktivitas tersebut. Oleh karena itu, digunakan model pembelajaran yang dapat meningkatkan aktivitas dan hasil belajar peserta didik.

Menurut Trianto model pembelajaran adalah kerangka konseptual yang melukiskan prosedur sistematik dalam mengorganisasikan pengalaman belajar untuk mencapai tujuan belajar tertentu dan berfungsi sebagai pedoman bagi perancang pembelajaran dan para guru dalam merancang dan melaksanakan pembelajaran. Model pembelajaran ada yang dapat dilakukan secara individu dan kelompok (Kurniawati, 2018).

Salah satu model pembelajaran yang dapat meningkatkan aktivitas belajar peserta didik adalah model PBL (Problem Based Learning). Menurut Arrends dalam (Laili, 
2018), PBL juga dapat meningkatkan penguasaan konsep, karena PBL merupakan salah satu model pembelajaran aktif yang ditandai dengan adanya peran aktif peserta didik dalam belajar. Pendapat tersebut, diperkuat dengan pendapat Fathurrohman (2017:113) yang mengatakan bahwa Problem Based Learning adalah suatu model yang melibatkan peserta didik untuk memecahkan suatu masalah melalui tahap-tahap metode ilmiah sehingga peserta didik dapat mempelajari pengetahuan yang berhubungan dengan masalah tersebut dan sekaligus memiliki keterampilan untuk memecahkan masalah.

Berbagai penelitian juga menunjukkan hasil yang positif menurut Gijselaers dalam Fathurrohman (2017:113) menunjukkan bahwa penerapan PBM menjadikan peserta didik mampu mengidentifikasi informasi yang diketahui dan diperlukan serta strategi yang diperlukan untuk menyelesaikan masalah. Berdasarkan pernyataan sebelumnya, maka diperlukan pengembangan perangkat pembelajaran berbasis model PBL. Jadi, perangkat pembelajaran berbasis model PBL ini sangat baik jika diterapkan dalam kegiatan pembelajaran.

\section{Metode Penelitian}

Jenis penelitian ini menggunakan penelitian dan pengembangan model ADDIE yang terdiri dari 5 tahap yaitu: 1) $\mathrm{A}=$ Analysis (menganalisis), 2) $\mathrm{D}=$ Desain (merancang), 3)
$\mathrm{D}=$ Development (mengembangkan), 4) $\mathrm{I}=$ Impelementation (mengimplementasikan), 5) $\mathrm{E}=$ Evaluation (mengevaluasi). Menurut Pribadi (2014:23) menjelaskan model ADDIE sebagai berikut:

1. Analysis, tahap ini digunakan untuk menentukan masalah dan solusi yang tepat dan menentukan kompetensi peserta didik.

2. Design, tahap ini digunakan untuk menentukan kompetensi khusus, metode, bahan ajar, dan strategi pembelajaran.

3. Development, pada tahap ini digunakan untuk memproduksi program dan bahan ajar yang akan digunakan dalam program pembelajaran.

4. Implementation, pada tahap ini digunakan untuk melaksanakan program pembelajaran dengan menerapkan desain atau spesifikasi program pembelajaran

5. Evaluation, pada tahap ini digunakan untuk melakukan evaluasi program pembelajaran dan hasil belajar.

Ujicoba terhadap perangkat pembelajaran yang dikembangkan, dilaksanakan pada kelas $\mathrm{V}$ di tiga $\mathrm{SD}$ di Kabupaten Rembang, yang dilakukan di SDN 2 Logede, SDN Kedungtulup dan SDN 1 Sendangmulyo. Jumlah peserta didik kelas V SDN 2 Logede berjumlah 11 peserta didik, kelas V SDN Kedungtulup berjumlah 16 peserta didik, dan peserta didik kelas V SDN 1 Sendangmulyo berjumlah 23 peserta didik.

Teknik pengumpulan data terdiri dari: 
1. Data uji kevalidan, berisi lembar validasi perangkat pembelajaran yang digunakan untuk memperoleh informasi tentang kualitas perangkat pembelajaran berdasarkan penilaian para validator ahli materi dan media.

2. Data uji kepraktisan, diperoleh dari instrumen penelitian berupa angket respon guru dan angket respon peserta didik.

3. Data uji keefektifan, diperoleh dari instrumen tes pada subtema komponen ekosistem yang terdapat pada LKPD.

Instrumen pengumpulan data pada penelitian ini, diperlukan untuk mengukur efektifitas perangkat pembelajaran yang dikembangkan adalah:

1. Lembar wawancara, diberikan kepada guru kelas V SDN 2 Logede, SDN Kedungtulup, dan SDN 1 Sendangmulyo pada saat studi pendahuluan.

2. Angket, digunakan untuk penilaian perangkat pembelajaran, yang berisi pernyataan penilaian mengenai perangkat pembelajaran yang dikembangkan.

a. Angket validasi penilaian.

$$
\text { Pengembangan perangkat }
$$

pembelajaran yang dibuat dikatakan valid jika hasil penilaian validator menunjukkan nilai keseluruhan aspek dan untuk semua aspek minimal berada pada kategori cukup valid.

b. Angket skala respon guru dan peserta didik.
Angket ini digunakan untuk mengetahui respon guru dan peserta didik setelah menggunakan produk yang dikembangkan oleh peneliti. angket tanggapan guru terhadap perangkat pembelajaran berbasis model PBL yang terdiri dari silabus, RPP, LKPD dan modul bahan ajar. Kemudian peserta didik diberikan angket tanggapan terhadap modul bahan ajar berbasis model PBL.

3. Tes Subtema Komponen Ekosistem, tes ini digunakan untuk mengetahui tingkat penguasaan peserta didik terhadap materi yang telah diajarkan. Pembelajaran dikatakan efektif jika minimal $80 \%$ peserta didik tuntas dari KKM (Kriteria Ketuntasan Minimal) dengan ketuntasan individu $\geq 65 \%$.

Teknik analisis data yang diperoleh dalam penelitian ini dikelompokkan menjadi tiga, yaitu analisis kevalidan, kepraktisan dan keefektifan.

1. Analisis kevalidan

Kevalidan produk dapat diketahui berdasarkan penilaian para validator ahli materi dan media. Data yang sudah dikumpulkan kemudian dianalisa dengan menghitung jumlah skor yang diperoleh. Analisis skor yang digunakan peneliti yaitu analisis deskriptif dengan langkahlangkah sebagai berikut: 
a. Data yang diperoleh dari ahli materi dan ahli media pembelajaran berupa data kualitatif diubah menjadi data kuantitatif dengan ketentuan dibawah ini.

Tabel 1. Pemberian Skor

\begin{tabular}{cc}
\hline Keterangan & Skor \\
\hline Sangat baik & 5 \\
\hline Baik & 4 \\
\hline Cukup & 3 \\
\hline Kurang & 2 \\
\hline Sangat Kurang & 1
\end{tabular}

b. Setelah data terkumpul, kemudian menghitung skor yang diperoleh dari hasil validasi angket.

c. Menghitung jumlah skor ideal butir (kriterium) untuk seluruh aspek pada angket validasi.

d. Selanjutnya dengan menghitung persentase angka dari analisis data yang telah dilakukan dengan rumus berikut:

Presentase $=\frac{\Sigma \text { skor total }}{\text { skor ideal }} \times 100 \%$

(Purwanto, 2002:102)

Tabel 2. Kriteria Kelayakan Media Pembelajaran

\begin{tabular}{|c|c|c|c|}
\hline No. & $\begin{array}{c}\text { Nilai } \\
\text { validitas }\end{array}$ & $\begin{array}{c}\text { Kriteria } \\
\text { validitas }\end{array}$ & Keterangan \\
\hline 1. & $\begin{array}{l}81,00- \\
100,00\end{array}$ & $\begin{array}{c}\text { Sangat } \\
\text { layak }\end{array}$ & Sangat baik digunakan. \\
\hline
\end{tabular}

2. 61,00 - Layak Boleh digunakan

$80,00 \quad$ dengan revisi kecil.

3. 41,00 - Cukup Boleh digunakan 60,00 layak dengan revisi besar.

\begin{tabular}{lllll}
\hline 4. & $21,00-$ & Kurang & Tidak & boleh \\
& 40,00 & layak & digunakan. & \\
\hline 5. & $00,00-$ & Tidak & Tidak & boleh \\
& 20,00 & layak digunakan. & \\
\hline
\end{tabular}

e. Dari persentase yang telah diperoleh kemudian ditransformasikan ke dalam kalimat yang bersifat kualitatif.

2. Analisis kepraktisan

Data uji kepraktisan perangkat pembelajaran diperoleh berdasarkan hasil penilaian dari gurudan peserta didik untuk menyatakan dapat tidaknya produk diterapkan di lapangan berdasarkan persepsi dan pengalamannya. Data yang telah diperoleh kemudian dianalisa sama seperti analisa uji kevalidan.

3. Analisis keefektifan

Menurut Aminullah (2018), Pencapaian hasil belajar diarahkan pada pencapaian secara individu dan klasikal. Peserta didik dikatakan berhasil (tuntas) apabila memperoleh nilai lebih besar atau sama dengan nilai $\mathrm{KKM}$ (Nilai $\geq \mathrm{KKM}$ ). Pembelajaran dikatakan berhasil secara klasikal jika minimal $80 \%$ peserta didik mencapai nilai tuntas. Penentuan hasil belajar peserta didik berdasarkan skor yang diperoleh dihitung menggunakan rumus:

$$
\mathrm{N}=\frac{w}{n} \times 100 \%
$$




\section{Keterangan:}

$\mathrm{N}=$ Nilai yang diperoleh peserta didik

$\mathrm{W}=$ Jumlah soal benar

$\mathrm{n}$ = Banyaknya item soal

Kemudian selanjutnya mengkategorikan hasil belajar peserta didik berdasarkan kategorisasi standar yang ditetapkan oleh Departemen Pendidikan dan Kebudayaan, sebagai berikut:

Tabel 3. Kategorisasi Hasil Belajar

\begin{tabular}{lll}
\hline No & \multicolumn{1}{c}{ Tingkat } \\
& \multicolumn{1}{c}{ Kategori } \\
\hline 1. & $85-100$ & Sangat tinggi \\
\hline 2. & $65-84$ & Tinggi \\
\hline 3. & $55-64$ & Sedang \\
\hline 4. & $35-54$ & Rendah \\
\hline 5. & $0-34$ & Sangat Rendah \\
\hline
\end{tabular}

\section{Hasil dan Pembahasan}

Uji kelayakan perangkat pembelajaran berbasis model PBL pada subtema komponen ekosistem untuk peserta didik kelas V Sekolah Dasar melalui proses validasi dari tiga validitor ahli materi dan media:

Tabel 1. Hasil Validitas Ahli Materi dan

Media terhadap Perangkat Pembelajaran

(Silabus dan RPP) Berbasis Model PBL

\begin{tabular}{|c|c|c|c|}
\hline No Instansi & Ahli & Persentase & Kriteria \\
\hline $\begin{array}{l}\text { Universitas } \\
\text { 1. PGRI } \\
\text { Semarang }\end{array}$ & $\begin{array}{c}\text { Materi } \\
\text { dan }\end{array}$ & $89,23 \%$ & $\begin{array}{l}\text { Sangat } \\
\text { Layak }\end{array}$ \\
\hline 2. Universitas & III) & $86,15 \%$ & Sangat \\
\hline
\end{tabular}

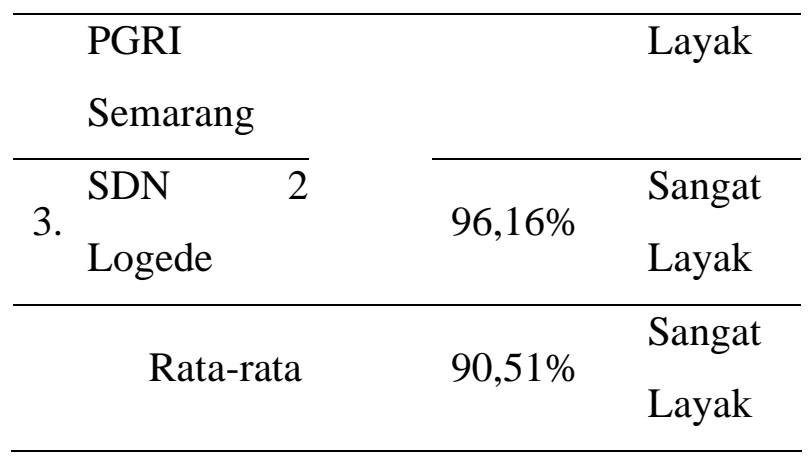

Berdasarkan tabel 1 dapat diketahui bahwa perangkat pembelajaran (silabus dan RPP) berbasis model PBL sangat layak digunakan dalam kegiatan pembelajaran. Hal ini terlihat dari hasil di atas yang menunjukkan bahwa rata-rata persentase penilaian ahli materi dan media terhadap perangkat pembelajaran (Silabus dan RPP) berbasis model PBL sebesar 90,51\% dengan kriteria "Sangat Layak".

Tabel 2. Hasil Validitas Ahli Materi dan Media terhadap Modul Bahan Ajar Berbasis Model PBL

\begin{tabular}{|c|c|c|c|c|}
\hline No & Instansi & Ahli & Persentase & Kriteria \\
\hline \multirow{3}{*}{1.} & Universitas & \multirow{4}{*}{ Materi } & \multirow{3}{*}{$94,78 \%$} & \multirow{3}{*}{$\begin{array}{l}\text { Sangat } \\
\text { Layak }\end{array}$} \\
\hline & PGRI & & & \\
\hline & Ser & & & \\
\hline \multirow{4}{*}{2.} & ULimito & & & \\
\hline & Universitas & $d a n$ & \multirow{3}{*}{$81,73 \%$} & Sanoat \\
\hline & PGRI & 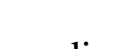 & & \\
\hline & Semarang & & & \\
\hline \multirow{2}{*}{3.} & SDN 2 & & \multirow{2}{*}{$95,65 \%$} & Sangat \\
\hline & Logede & & & Layak \\
\hline \multirow{2}{*}{\multicolumn{2}{|c|}{ Rata-rata }} & & \multirow{2}{*}{$91,05 \%$} & Sangat \\
\hline & & & & Layak \\
\hline
\end{tabular}


Berdasarkan tabel 2 dapat diketahui bahwa modul bahan ajar berbasis model PBL sangat layak digunakan dalam kegiatan pembelajaran. Hal ini terlihat dari hasil di atas yang menunjukkan bahwa rata-rata persentase penilaian ahli materi dan media terhadap modul bahan ajar berbasis model PBL sebesar 91,05\% dengan kriteria "Sangat Layak".

Tabel 3. Hasil Angket Tanggapan Guru terhadap Perangkat Pembelajaran (Silabus dan RPP) Berbasis Model PBL

\begin{tabular}{|c|c|c|c|}
\hline No. & Instansi & Persentase & Kriteria \\
\hline 1. & SDN 2 Logede & $94,28 \%$ & $\begin{array}{l}\text { Sangat } \\
\text { Layak }\end{array}$ \\
\hline 2. & SDN Kedungtulup & $80 \%$ & Layak \\
\hline 3. & $\begin{array}{l}\text { SDN } \\
\text { Sendangmulyo }\end{array}$ & $94,28 \%$ & $\begin{array}{l}\text { Sangat } \\
\text { Layak }\end{array}$ \\
\hline & Rata-rata & $89,52 \%$ & $\begin{array}{l}\text { Sangat } \\
\text { Layak }\end{array}$ \\
\hline
\end{tabular}

Berdasarkan tabel 3 dapat diketahui bahwa modul bahan ajar berbasis model PBL sangat layak digunakan dalam kegiatan pembelajaran. Hal ini terlihat dari hasil di atas yang menunjukkan bahwa rata-rata persentase tanggapan guru terhadap perangkat pembelajaran (Silabus dan RPP) berbasis model PBL sebesar 89,52\% dengan kriteria "Sangat Layak".

Tabel 4. Hasil Angket Tanggapan Guru terhadap Modul Bahan Ajar Berbasis Model PBL

\begin{tabular}{|c|c|c|c|}
\hline No. & Instansi & Persentase & Kriteria \\
\hline \multirow{2}{*}{1.} & \multirow{2}{*}{ SDN 2 Logede } & \multirow{2}{*}{$98 \%$} & Sangat \\
\hline & & & Layak \\
\hline 2. & SDN Kedungtulup & $80 \%$ & Layak \\
\hline \multirow{2}{*}{3.} & SDN & \multirow{2}{*}{$86 \%$} & Sangat \\
\hline & Sendangmulyo & & Layak \\
\hline \multirow{2}{*}{\multicolumn{2}{|c|}{ Rata-rata }} & \multirow{2}{*}{$88 \%$} & Sangat \\
\hline & & & Layak \\
\hline
\end{tabular}

Berdasarkan tabel 4 dapat diketahui bahwa modul bahan ajar berbasis model PBL sangat layak digunakan dalam kegiatan pembelajaran. Hal ini terlihat dari hasil di atas yang menunjukkan bahwa rata-rata persentase tanggapan guru terhadap perangkat pembelajaran (modul bahan ajar) berbasis model PBL sebesar $88 \%$ dengan kriteria "Sangat Layak".

Tabel 5. Hasil Angket Tanggapan Peserta Didik terhadap Modul Bahan Ajar Berbasis Model PBL

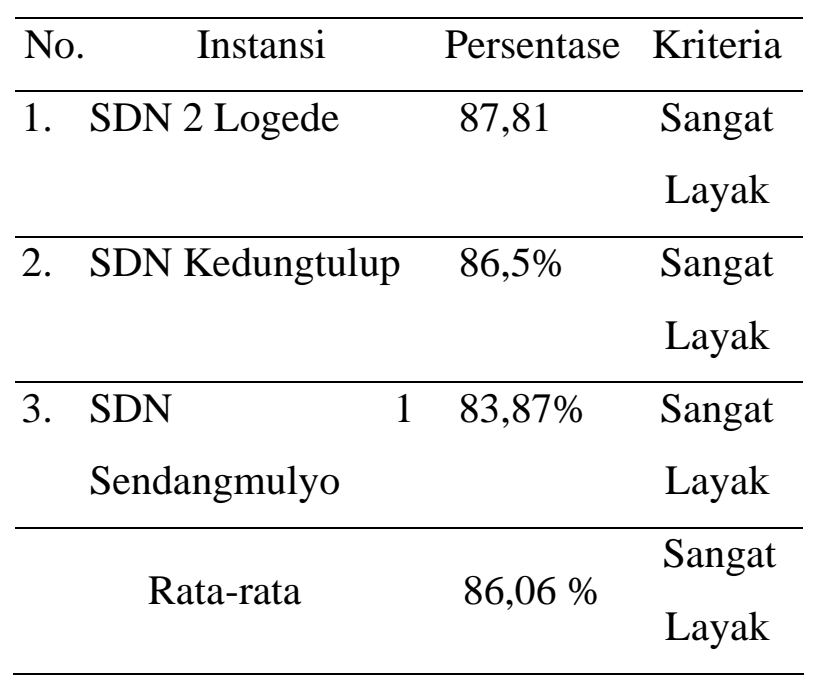

Berdasarkan tabel 5 dapat diketahui bahwa modul bahan ajar berbasis model 
Problem Based Learning sangat layak digunakan dalam kegiatan pembelajaran. Hal ini terlihat dari hasil di atas yang menunjukkan bahwa rata-rata persentase tanggapan peserta didik terhadap modul bahan ajar berbasis model PBL sebesar 86,06\% dengan kriteria "Sangat Layak".

Tabel 6. Hasil Belajar Peserta Didik

\begin{tabular}{|l|l|l|l|}
\hline No. & \multicolumn{1}{|c|}{ Instansi } & $\begin{array}{r}\text { Rata- } \\
\text { rata }\end{array}$ & $\begin{array}{l}\text { Banyak } \\
\text { Peserta Didik } \\
\text { Tuntas }\end{array}$ \\
\hline 1. & SDN 2 Logede & 89,09 & $\begin{array}{l}11 \text { peserta } \\
\text { didik }\end{array}$ \\
\hline 2. & $\begin{array}{l}\text { SDN } \\
\text { Kedungtulup }\end{array}$ & 81,07 & $\begin{array}{l}14 \\
\text { didik }\end{array}$ \\
\hline 3. & $\begin{array}{l}\text { SDN } \\
\text { Sendangmulyo }\end{array}$ & 81,18 & $\begin{array}{l}16 \text { peserta } \\
\text { didik }\end{array}$ \\
\hline \multicolumn{2}{|c|}{ Rata-rata } & \multicolumn{2}{|c|}{83,78} \\
\hline
\end{tabular}

Berdasarkan analisis data pada tabel 6 , ketuntasan belajar peserta didik pada aspek pengetahuan telah melebihi nilai KKM.

Berdasarkan hasil penelitian menunjukkan bahwa perangkat pembelajaran berbasis model PBL memenuhi kriteria valid berdasarkan hasil penilaian ahli materi dan media. Perangkat pembelajaran berbasis model PBL berupa silabus dan RPP memenuhi kriteria valid dengan rata-rata dengan rata-rata 90,51\% dengan kategori "Sangat Layak". Perangkat pembelajaran berbasis model PBL berupa modul bahan ajar memenuhi kriteria valid dengan rata-rata $89,52 \%$ dengan kategori "Sangat Layak". Perangkat pembelajaran berbasis model PBL memenuhi kriteria praktis berdasarkan hasil tanggapan peserta didik dengan rata-rata $86,06 \%$ dengan kriteria "Sangat Layak" dan guru dengan rata-rata sebesar $88 \%$ dengan klasifikasi "Sangat Layak". Perangkat pembelajaran berbasis model PBL memenuhi kriteria efektif berdasarkan hasil belajar peserta didik di tiga SD di Kabupaten Rembang dengan rata-rata 83,78 dengan kriteria "Tinggi".

Jadi, perangkat pembelajaran berbasis model PBL pada Subtema Komponen Ekosistem layak digunakan sebagai penunjang perangkat pembelajaran peserta didik kelas $\mathrm{V}$ SD di Kabupaten Rembang yang memenuhi kriteria valid, praktis, dan efektif. Penelitian ini didukung oleh penelitian-penelitan yang telah dilakukan sebelumnya. Dalam Tanjung (2018), penelitian yang dilakukan oleh Dwijananti \& Yulianti (2010) mengenai pengembangan kemampuan berpikir kritis mahasiswa melalui pembelajaran berdasarkan masalah pada mata kuliah fisika lingkungan. Hasil yang diperoleh menunjukkan bahwa kemampuan berpikir kritis siswa dapat dikembangkan dengan model menggunakan model PBM. Aspek-aspek berpikir kritis yang dapat dikembangkan diantaranya: mengklasifikasi, mengasumsi, memprediksi, membuat hipotesis, mengevaluasi, 
menganalisis dan membuat kesimpulan. Penelitian ini menunjukkan bahwa penggunaan model PBM dapat meningkatkan kemampuan berpikir kritis.

Penelitian yang dilakukan oleh Imamah (2016) mengenai pengembangan perangkat pembelajaran berbasis model PBL dalam meningkatkan hasil belajar siswa kelas IV SD juga menunjukkan bahwa model PBL dapat meningkatkan hasil belajar siswa atau efektif diterapkan.

Hasil Penelitian Renol Afrizon dalam Niki (2019) menyatakan bahwa model Problem Based Instruction dalam pembelajaran IPA selain dapat meningkatkan perilaku berkarakter siswa, tetapi juga mampu meningkatkan keterampilan berpikir kritis siswa.

Beberapa penelitian tersebut sejalan dengan pendapat Arrends dalam Laili (2018) yang mengatakan bahwa, PBL juga dapat meningkatkan penguasaan konsep, karena PBL merupakan salah satu model pembelajaran aktif yang ditandai dengan adanya peran aktif peserta didik dalam belajar. Pendapat tersebut, diperkuat dengan pendapat Fathurrohman (2017:113) yang mengatakan bahwa Problem Based Learning adalah suatu model yang melibatkan peserta didik untuk memecahkan suatu masalah melalui tahaptahap metode ilmiah sehingga peserta didik dapat mempelajari pengetahuan yang berhubungan dengan masalah tersebut dan sekaligus memiliki keterampilan untuk memecahkan masalah.

Jadi, hasil penelitian yang telah dilakukan peneliti menunjukkan bahwa perangkat pembelajaran berbasis model PBL pada subtema komponen ekosistem valid, praktis dan efektif serta layak digunakan di kelas V SD di Kabupaten Rembang. Hal tersebut didukung dengan penelitian-penelitian relevan yang telah dilakukan sebelumnya.

\section{Kesimpulan}

Perangkat pembelajaran berbasis model PBL Sangat Layak digunakan berdasarkan penilaian oleh tiga ahli materi dan media dan telah memenuhi kriteria valid.

Perangkat pembelajaran berbasis model PBL Sangat Layak digunakan di kelas V Sekolah Dasar, berdasarkan angket tanggapan guru kelas V SDN 2 Logede, SDN Kedungtulup dan SDN 1 Sendangmulyo. Perangkat pembelajaran berbasis model PBL pada subtema komponen ekosistem telah memenuhi kriteria praktis.

Berdasarkan hasil belajar peserta didik dalam mengerjakan LKPD pada pembelajaran 1, perangkat pembelajaran berbasis model PBL yang dikembangkan oleh peneliti mendapat tingkat keefektifan "Layak" digunakan untuk meningkatkan hasil belajar peserta didik pada subtema komponen ekosistem. Sehingga, perangkat pembelajaran berbasis model PBL pada subtema komponen ekosistem telah memenuhi kriteria efektif. 


\section{Daftar Pustaka}

Aminullah. 2018. "Pengembangan Bahan Ajar Biologi Pokok Pembahasan Sistem Reproduksi Manusia Berbasis Konstruktivisme Pada Siswa Kelas XI Sma Negeri 1 Baraka Kabupaten Enrekang". Jurnal Pendidikan EDUMASPUL. Vol 2, No. 2. Diakses 08 Agustus 2020. Online: https://ummaspul.ejournal.id/maspuljr/article/view/5/4

Fathurrohman, Muhammad. 2017. MODELMODEL PEMBELAJARAN INOVATIF: Alternatif Desain Pembelajaran yang Menyenangkan. Jogjakarta: ar-Ruzz Media.

Herayanti, Lovy, dkk. 2018. "Pengembangan Perrangkat Pembelajaran Berbasis Masalah Menggunakan Media Moodle untuk Meningkatkan Keterampilan Berpikir Kritis Mahasiswa pada Materi Gelombang". Jurnal Pendidikan Fisika dan Teknologi. Vol. 4, No. 2. Diakses 23 Oktober 2019.2 Online: http://jurnalfkip.unram.ac.id/index.php/J PFT/article/view/803/pdf

Imamah, Habibatul. 2016. "Pengembangan Perangkat Pembelajaran Berbasis Model PBL Subtema Lingkungan Tempat Tinggalku dalam Meningkatkan Hasil Belajar Siswa Kelas IV Sekolah Dasar". Jurnal Review Pendidikan Dasar: Jurnal Kajian Pendidikan dan Hasil Penelitian. Vol. 2, No. 3. Diakses pada 25 Oktober $2019 . \quad$ Online

https://journal.unesa.ac.id/index.php/PD/ article/view/1661

Kurniawati, Rustopo, dan Fine Reffiane. 2018. "Pengembangan Media Pop-Up Elektrik Berbantu Model Stad untuk Meningkatkan Hasil Belajar IPA Kelas III Sekolah Dasar". Jurnal Sekolah. Vol. 3, No. 1. Diakses: 8 Desember 2019. Online:https://jurnal.unimed.ac.id/2012/i ndex.php/js/article/view/11634/10176

Kusmayadi, T. A., \& Riyadi, R. (2016). Pengembangan Perangkat Pembelajaran Teams Games Tournament (Tgt) Dengan Pendekatan Saintifik Pada Materi
Operasi Aljabar SMP Tahun Pelajaran 2014/2014. Jurnal Pembelajaran Matematika, 4(3).

Laili, Alik Mustafidal dan Eries Norma Yusmita. 2018. "Pengembangan Model Problem Based Learning untuk Meningkatkan Penguasaan Konsep Mahasiswa PGSD pada Matakuliah Pendidikan SAINS SD". Inventa Jurnal Pendidikan Guru Sekolah Dasar. Vol. 2, No II. Diakses pada 20 Oktober 2019. Online:

http://jurnal.unipasby.ac.id/index.php/jur nal_inventa/article/view/1644/1462

Machali, Imam. 2014. "Kebijakan Perubahan Kurikulum 2013 dalam Menyongsong Indonesia Emas 2045". Jurnal Pendidikan Islam. Vol. III, No. 1. Diakses: 20 Agustus 2020. Online: http://ejournal.uinsuka.ac.id/tarbiyah/index.php/JPI/article/ view/1158/1054

Minggele, Darmanto. 2019. "Pengembangan Perangkat Pembelajaran Kooperatif Tipe STAD untuk Meningkatan Motivasi Belajar Siswa Kelas VIII Pada Materi Faktorisasi Suku Aljabar". Jurnal Penelitian Hukum dan Pendidikan. Vol. 18, No. 1. Diakses : 15 Oktober 2019. Online:

https://scholar.google.co.id/citations?hl= id\&user=QTwVjzsAAAAJ\#d=gs_md_ci $\underline{\text { ta- }}$

$\mathrm{d} \& \mathrm{u}=\% 2 \mathrm{Fcitations} \% 3 \mathrm{Fview}$ op\%3Dvie w_citation\%26hl\%3Did\%26user\%3DQ TwVjzsAAAAJ\%26citation_for_view\% 3DQTwVjzsAAAAJ\%3Aux6o8ySG0sC\%26tzom\%3D-420

Niki, Medyata Rika, Elsje Theodora, dan Susilo. 2019. "Pengembagan Perangkat Pembelajaran Model Problem Based Instruction (PBI) terhadap Hasil Belajar Siswa dan Kemampuan Menulis Laporan Ilmiah". Biodik: Jurnal Ilmiah Pendidikan Biologi. Viol. 5, No. 2. Diakses pada 25 Oktober 2019. Online: https://www.onlinejournal.unja.ac.id/biodik/article/view/68 $\underline{81}$ 
Pribadi, Benny A. 2014. Desain dan Pengembangan Program Pelatihan Berbasis Kompetensi Implementasi Model ADDIE. Jakarta: Kencana.

Purwanto, M Ngalim. 2002. Prinsip-Prinsip dan Teknik Evaluasi Pengajaran. Bandung: PT Remaja Rosdakarya.

Sary, Ryky Mandar, Djariyo, dan Ihtiya Kusuma Dewi. 2015. "Model Problem Based Learning untuk Menumbuhkan Kemampuan Berpikir Kritis Siswa di Sekolah Dasar". Jurnal Malih Peddas. Vol. 5, No. 5. Diakses 21 Oktober 2020. Online:

http://journal.upgris.ac.id/index.php/mali hpeddas/article/view/847

Susanto, Joko. 2012. "Pengembangan Perangkat Pembelajaran Berbasis Lesson Study dengan Kooperatif Tipe Numbered Heads Together untuk Meningkatkan Aktivitas dan Hasil Belajar IPA di SD”. Jurnal Of Primary Education. Vol. 1, No. 2. Diakses: 16 Oktober 2019.2 Online: https://journal.unnes.ac.id/sju/index.php/ ipe/article/view/785/811

Tanjung, Henra Saputra dan Siti Aminah Nababan. 2018. "Pengembangan Perangkat Pembelajaran Berorientasi Model Pembelajaran Berbasis Masalah (PBM) untuk Meningkatkan Kemampuan Berpikir Kritis Siswa SMA Se-Kuala Nagan Raya Aceh". Genta
Mulia: Jurnal Ilmiah Pendidikan. Vol. IX, No. 2. Diakses pada 20 Oktober 2019. Online

https://ejournal.stkipbbm.ac.id/index.php /gm/article/view/168/156

Undang-Undang Dasar Negara Republik Indonesia No. 20 Tahun 2003 Pasal 1 ayat 1 tentang Sistem Pendidikan Nasional. Diakses: 18 Oktober 2019. Online:

http://luk.staff.ugm.ac.id/atur/UU202003Sisdiknas.pdf

Wicaksono, Vicky Dwi. 2018. "Pengembangan Perangkat Asesmen Autentik pada Tema Makanan Sehat dan Bergizi Kelas IV Sekolah Dasar". Inventa Jurnal Pendidikan Guru Sekolah Dasar. Vol. II, No. 2. Diakses pada 18 Oktober 2019.2 Online: http://jurnal.unipasby.ac.id/index.php/jur nal_inventa/article/view/1650/1467

Yusuf, Mochamad. 2018. "Pengembangan Perangkat Pembelajaran Berbasis Model Problem Based Learning untuk Meningkatkan Kemampuan Berpikir Kritis Peserta Didik Sekolah Dasar". Paedagoria: Jurnal Kajian, Penelitian dan Pengembangan Kependidikan. No.9, No. 1. Diakses pada 19 Oktober 2019. Online:

http://journal.ummat.ac.id/index.php/pae dagoria/article/view/269/224 s 